\title{
THE GEOLOGY OF AUSTRALIA
}

\author{
Third edition
}

The Geology of Australia documents the rich and spectacular heritage of the Australian continent over the last 4400 million years.

Now in its third edition, The Geology of Australia provides an easy-to-read, comprehensive overview of Australia's geology, landscapes and Earth resources. Beginning with the Precambrian rocks that hold clues to the origins of life and the development of an oxygenated atmosphere, it goes on to cover the warm seas, volcanism and episodes of mountain building that formed the eastern third of the Australian continent.

This illuminating history details the breakup of the supercontinents Rodinia and Gondwana, the times of previous glaciations, the development of climates and landscapes in modern Australia, and the creation of the continental shelves and coastlines.

This comprehensively revised third edition features:

- two new chapters on geological time and Paleozoic orogenic rock systems and mountain building

- new and updated illustrations and full-colour images

- a description of the origin of the Australian continent and landscapes in simple language.

From Uluru to the Great Dividing Range, from earthquakes to dinosaurs, from sapphires to the stars, The Geology of Australia explores the timeless forces that have shaped this continent.

Robert Henderson is an Emeritus Professor at James Cook University. He joined the academic staff of James Cook University in 1969 following a post-doctoral post as a Fulbright Fellow at Harvard University, and served as President of the Geological Society of Australia from 1998 to 2000 .

David Johnson completed a BSc at the University of Sydney and a PD at the University of Western Australia. He was a member of the academic staff at James Cook University from 1978 to 1998 and is now a retired geologist. 


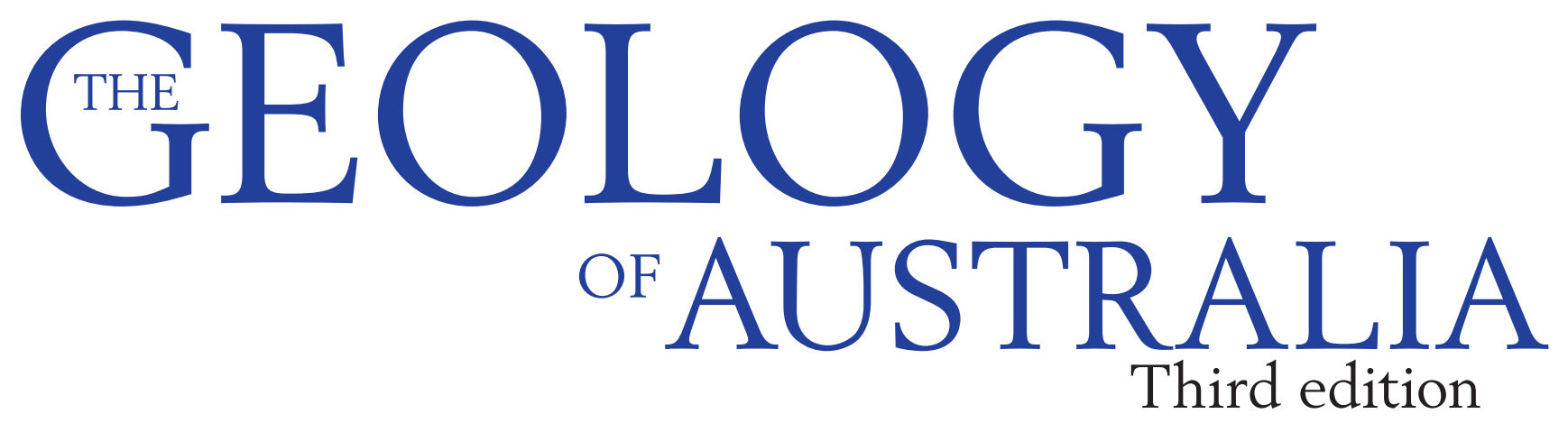

\section{ROBERT HENDERSON AND DAVID JOHNSON}




\section{CAMBRIDGE \\ UNIVERSITY PRESS}

477 Williamstown Road, Port Melbourne,VIC 3207, Australia

Cambridge University Press is part of the University of Cambridge.

It furthers the University's mission by disseminating knowledge in the pursuit of education, learning and research at the highest international levels of excellence.

www.cambridge.org

Information on this title: www.cambridge.org/9781107432413

(C) Cambridge University Press 2016

This publication is copyright. Subject to statutory exception and to the provisions of relevant collective

licensing agreements, no reproduction of any part may take place without the written permission of Cambridge University Press.

First published 2004

Second edition 2009

Reprinted 2010,2012

Third edition 2016

Cover and text designed by Adrian Saunder

Typeset by Newgen Publishing and Data Services

Printed in Singapore by Markono Print Media Pte Ltd

A catalogue record for this publication is available from the British Library

A Cataloguing-in-Publication entry is available from the catalogue

of the National Library of Australia at www.nla.gov.au

ISBN 978-1-107-43241-3 Paperback

Reproduction and communication for educational purposes

The Australian Copyright Act 1968 (the Act) allows a maximum of one chapter or $10 \%$ of the pages of this work,

whichever is the greater, to be reproduced and/or communicated by any educational institution for its educational purposes provided that the educational institution (or the body that administers it) has given a remuneration notice to Copyright Agency Limited (CAL) under the Act.

For details of the CAL licence for educational institutions contact:

Copyright Agency Limited

Level 15, 233 Castlereagh Stree

Sydney NSW 2000

Telephone: (02) 93947600

Facsimile: (02) 93947601

E-mail:info@copyright.com.au

Reproduction and communication for other purposes

Except as permitted under the Act (for example a fair dealing for the purposes of study, research, criticism or

review) no part of this publication may be reproduced, stored in a retrieval system, communicated or transmitted in any form or by any means without prior written permission. All inquiries should be made to the publisher at the address above.

Cambridge University Press has no responsibility for the persistence or accuracy of URLs for external or third-party internet websites referred to in this publication and does not guarantee that any content on such websites is, or will remain, accurate or appropriate. 


\section{Contents}

Preface $\quad$ ix

Acknowledgements $\quad x$

Units of measurement and abbreviations xiii

\begin{tabular}{llr}
1 & Geology: An Australian perspective & 1 \\
\hline Connections & 1
\end{tabular}

Australia's present geological setting $\quad 11$

Summary

2 The Earth: A geology primer $\quad 23$

A model of the Earth $\quad 23$

$\begin{array}{ll}\text { Plate tectonics } & 27\end{array}$

Within-plate volcanics $\quad 33$

$\begin{array}{ll}\text { Crustal stress and its consequences } & 34\end{array}$

$\begin{array}{ll}\text { Minerals } & 38\end{array}$

$\begin{array}{ll}\text { Types of rocks } & 44\end{array}$

The shaping of the landscape $\quad 58$

$\begin{array}{ll}\text { Coastal and offshore areas } & 67\end{array}$

$\begin{array}{ll}\text { Summary } & 68\end{array}$

$3 \quad$ Telling geological time: The great canvas $\quad 69$

$\begin{array}{ll}\text { Developing a timescale } & 70\end{array}$

Adding time units to the timescale $\quad 73$

$\begin{array}{ll}\text { Dating by magnetic signature } & 79\end{array}$

Dating within the span of humankind $\quad 81$

Summary

$4 \quad$ The cratons: Building the core of Precambrian rocks $\quad 85$

$\begin{array}{ll}\text { The original Earth } & 85\end{array}$

$\begin{array}{ll}\text { The Archean } & 89\end{array}$

$\begin{array}{ll}\text { The Proterozoic } & 97\end{array}$

The origin of life $\quad 100$

The Rodinian supercontinent breakup 107

$\begin{array}{ll}\text { Summary } & 107\end{array}$

$5 \quad$ Mountain building: Paleozoic orogenic rock systems $\quad 109$

$\begin{array}{ll}\text { Assembly of the Gondwana supercontinent } & 109\end{array}$

Orogenic processes and patterns 110

The Tasman Orogenic Zone 113

The historical record of the orogenic sedimentary systems $\quad 129$

Summary 130 
Part of Gondwana 131

Seascapes and landscapes $\quad 135$

Deep crustal processes 141

Summary 146

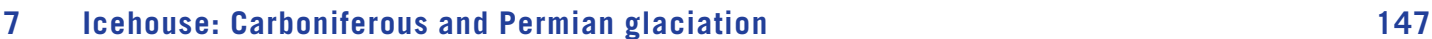

The setting and relationships 148

A glaciated continent 148

Development of the coal basins 158

Summary 170

$8 \quad$ Mesozoic warming: The great inland plains and seas 171

Warming of the inland plains $\quad 172$

The Tasmanian dolerites 182

Continental breakup and inland seas 183

Cretaceous volcanism 186

$\begin{array}{ll}\text { Rainforests, dinosaurs and sea monsters } & 187\end{array}$

Summary 194

9 The birth of modern Australia: Flowering plants, mammals and deserts $\quad 195$

Australia emerges 196

The rainforests 204

Australian fauna through the Cenozoic $\quad 209$

Consequences from growth of the ice-caps $\quad 211$

The arid interior 213

Summary 219

10 Fossils: The Australian record of past life in context $\quad 221$

$\begin{array}{ll}\text { Invertebrate fossils } & 227\end{array}$

Vertebrate fossils $\quad 234$

The Australian fossil record

Summary 250

11 The land stirs: Volcanoes and the eastern highlands 251

$\begin{array}{ll}\text { The volcanic provinces } & 251\end{array}$

The seamount chains 265

Origins of the Great Divide and Great Escarpment 267

Summary 271 
12 The outline and submerged terrace: Building the continental shelf and coastlines

The origin of the outline $\quad 274$

Changing sea level $\quad 278$

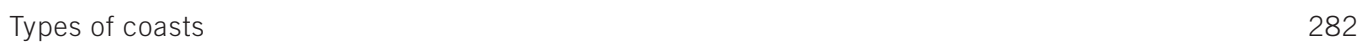

The Australian coastline $\quad 293$

$\begin{array}{ll}\text { Summary } & 304\end{array}$

13 The coral reefs: Unique parts of the continental shelf 305

$\begin{array}{ll}\text { Australian coral reefs } & 306\end{array}$

$\begin{array}{ll}\text { The Great Barrier Reef } & 307\end{array}$

$\begin{array}{ll}\text { Summary } & 325\end{array}$

14 Patterns of change: Cycles in Australia's journey 327

Global wandering 328

Supercontinent cycles $\quad 329$

Exhuming rock systems to uncover past cycles

$\begin{array}{ll}\text { Climate cycles } & 337\end{array}$

Changing patterns of life $\quad 341$

Summary $\quad 345$

$\begin{array}{ll}\text { Epilogue } & 347\end{array}$

$\begin{array}{ll}\text { Sources and references } & 349\end{array}$

Index 369 


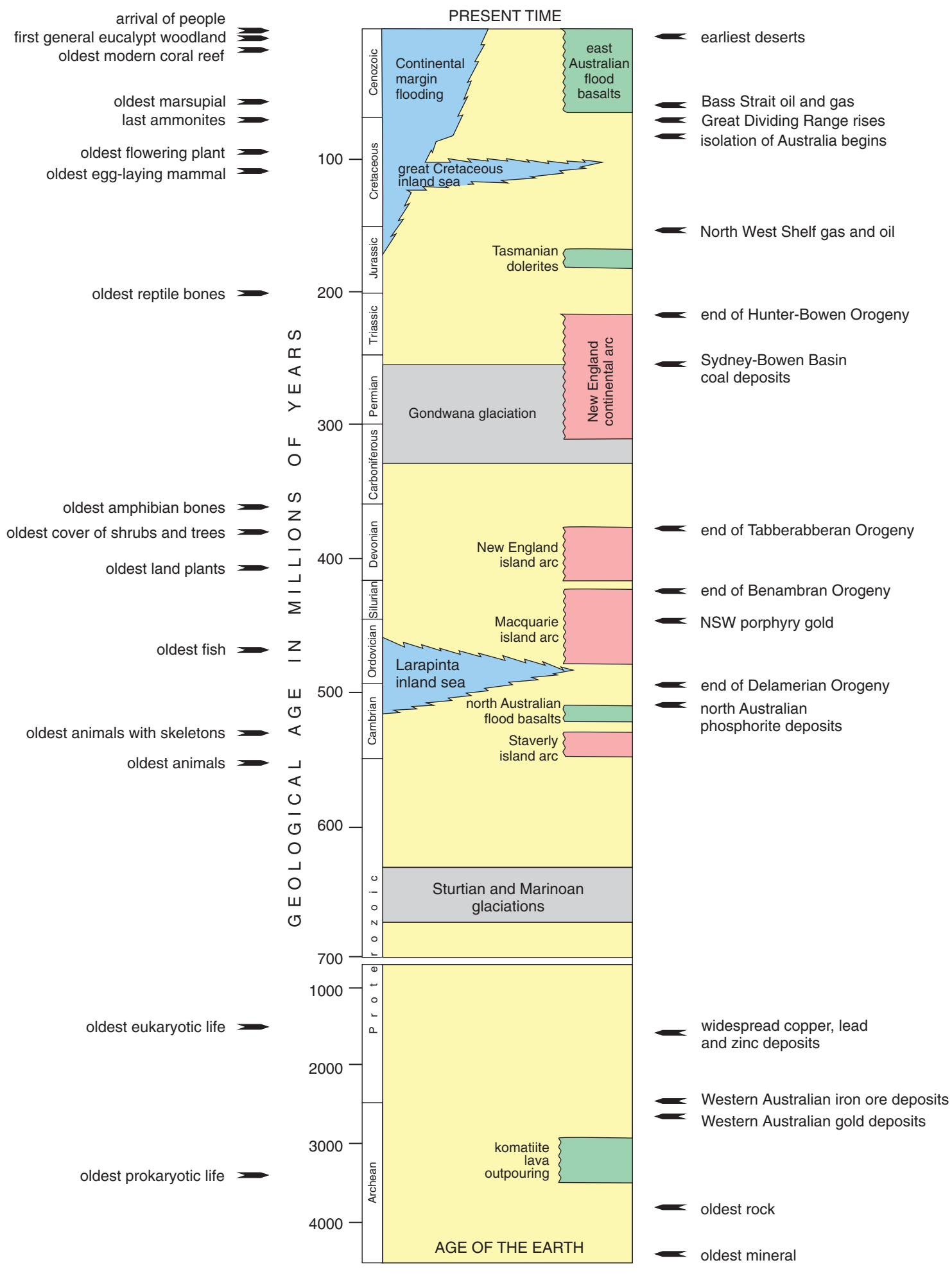




\section{Preface}

The begetting of Australia as we know it was a very protracted process, the pathway of which is written in the rocks. This is true of every continent, and for each the pathway was unique, although many of the treads were shared.The last steps in the Australian journey were of special importance, because they gave rise to the unique environmental attributes which characterise this island continent.

This volume tells the story of how Australia came to be the way it is. It gives a time and process context to the rich and involved preceding history - a forever-fascinating tale. Its main parts are long known and well established, but the story is embellished every year by new research. The pace of change, both in the unfolding of new parts to the story and in the achievement of a tighter focus on broad-scale perspectives, is considerable. In just the seven years or so since the second edition of The Geology of Australia was crafted, much new information has come to light through research undertaken in universities, by government agencies and in the private sector.

The considerable physical assets of Australia are indelibly vested in its origins. These have exerted a powerful influence on the development of Australia as a nation. Two complementary streams of discovery have been running. One is pure research, knowledge for its own sake, which has unlocked the begetting pathway, the types of rock systems involved and the nature of the Earth's processes that applied in their origins. The other is the discovery, documentation and utilisation of Earth resources - minerals, rocks, oil and gas, along with soil and subsurface water with economic ends as the drivers. These two knowledge-based streams have intertwined from the days of early European settlement to the present.Their interaction has been highly productive, in discovering both how Australia came to be and how best to use its physical assets in nation building. The outcome has been to place Australian geoscience as top tier on a global scale, one of very few home-based science disciplines to achieve that international standing.

Knowledge of Australia's origins is profound, and our intention is to lay out that story as a simple, easily understood narrative. Our volume is supported by a bare-bones introduction to geology: rocks, minerals, fossils and importantly a thumbnail sketch of how the Earth works in process terms. This essential backdrop puts the begetting of Australia in context. As an aside, we hope that the volume will also serve many readers as a useful geoscience compendium of terms and concepts. 


\section{Acknowledgements}

The content of this book has been shaped by interaction over many decades with colleagues and students, and by absorbing their contributions to Australian geology through publication. The science of geology has a rich heritage in Australia, fostered in particular by the Geological Society of Australia. We have been very privileged by our involvement in Australian geoscience. We are particularly indebted to our departmental colleagues at James Cook University and to our host institution for its support through the provision of facilities, particularly comprehensive library access.

Presentation of the work has been greatly advantaged by cartographic and illustrative work by Adella Edwards and Stuart Johnson. Their talents and diligence have made a considerable contribution to the book and its capacity to communicate effectively.

Many friends, colleagues and organisations have generously provided advice on specific issues, photographs reproduced in the book and original figures either used unchanged or from which line diagrams have been reconstructed. They include Tracy Ainsworth, Ross Andrew, Mike Archer, Australian Museum, Australian Research Council Centre for Excellence in Coral Reef Studies, Mark Barley, Robin Beaman, Carlo Bento, Alex Bevan, Mary-Anne Binney, Gavin Birch, Eric Bird, Karen Black, Richard Blewett, Ted Brattstrom, John Brodie, Ted Bryant, Paul Candlin, Ray Cas, Allan Chivas, Jonathan Claoué-Long, Ben Cohen, Terry Coldham, Lindsay Collins, Marie Corkeron, Leon Costermans, Bruce Cowell, Keith Crook, Brett Davies, Patrick de Deckker, Mary Dettmann, Claus Diessel, Peter Doyle, Cynthia Ebinger, Chris Evenden, Mohuindeen Faiz, Chris Fergusson, Chris Fielding, Elizabeth Fredericks, Mike Gagan, Jim Gehling, Geological Society of America, Geological Society of Australia, Geological Survey of New South Wales, Geological Survey of Western Australia, Geoscience Australia, Mebus Geyh, David Gillieson, Vic Gostin, Great Barrier Reef Marine Park Authority, Kath Grey, Ken Grimes, Susan Hand, HarperCollins Publishers, Chris Herbert, Robert Hill, Rob Holm, Terry Hoshke, Laurie Hutton, Jim Jago, John Wiley \& Sons, Diane Jorgensen, Bill Laing, Jenny Lappin, John Long, Macmillan Publishers, Helene Martin, McGraw-Hill, Greg McNally, Ken McNamara, Mineralogical Society of America, Museum Victoria, NASA, New South Wales Department of Agriculture and Water Resources, Nick Oliver, Oxford University Press, Ken Page, Palaeontological Association, Barrie Pittock, Phillip Playford, Jaime Plaza, Ross Pogson, Austin Post, Queensland Department of Environment \& Heritage Protection, Queensland Department of Tourism and Events, Queensland Museum, Greg Retallack,John Rogers, Gideon Rosenbaum, Peter Roy, Andrew Rozefelds, Michael Rubenach, Richard Rudd, Mike Sandiford, Peter Schouten, Gordon Smith, Richard Smith, Society of Economic Geologists, Society for Sedimentary Geology, South Australian Museum, Carl Spandler, Frank Spear, Springer-Verlag, 
Jon Stephenson, Lin Sutherland, Thomas Nelson \& Sons, Peter Trusler, University of Chicago Press, John Valley, Fons Vandenberg, John Veevers, Patricia Vickers-Rich, Dave Waters, Western Australian Museum, Peter Whitehead, Simon Wilde, Wildlight, Paul Willis and Bob Young.

Antonietta Anello and Jodie Fitzsimmons have been most helpful and constructive in copy editing and maintaining momentum in finalising the draft of this edition; Nina Sharpe and the production staff of Cambridge University Press Australia and New Zealand have turned the manuscript into a published product.

As always we are grateful to our wives, Joy and Trish, for encouragement in our academic pursuits. Book writing is a long and exacting task to whose outcome personal support contributes in no small way. 


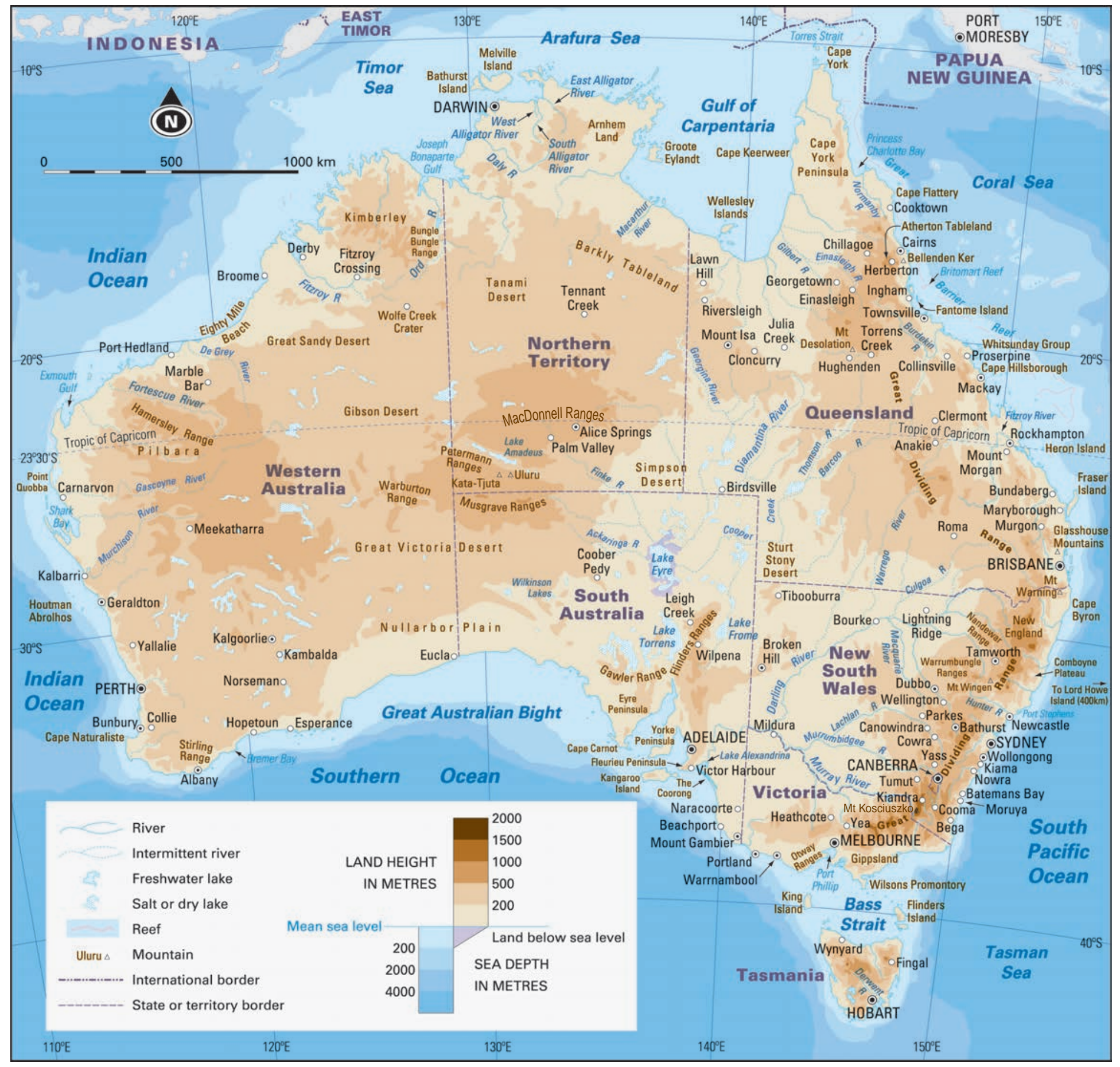

The main localities mentioned in this book. 


\section{Units of measurement and abbreviations}

\author{
Length \\ micrometre \\ millimetre \\ metre \\ kilometre \\ Slope \\ metre per kilometre
}

Area

square kilometre

\section{Volume}

cubic metre

cubic kilometre

Mass

kilogram

tonne

Power

watts

\section{Density}

kilogram per cubic metre

tonne per cubic metre

\section{Pressure}

$\mu \mathrm{m}$

$\mathrm{mm}$

$\mathrm{m}$

$\mathrm{km}$

$\mathrm{m} / \mathrm{km}$

(n)

$\mathrm{km}^{2}$

(2)

$$
\mathrm{m}^{3}
$$

$\mathrm{km}^{3}$

kilobar

kbar

Atmospheric pressure

hectopascal

$\mathrm{hPa}$

\section{Temperature}

degree Celsius

${ }^{\circ} \mathrm{C}$

\section{Time}

second

day

year

thousand years (kilo-annus) ka

million years (mega-annus, 106) Ma

billion (thousand million) years (giga-annus, $10^{9}$ ) Ga

\section{kg Speed}

t millimetre per year mm/yr

metre per million years $\quad \mathrm{m} / \mathrm{Ma}$

kilometre per second $\mathrm{km} / \mathrm{s}$

W kilometre per hour $\mathrm{km} / \mathrm{h}$

kilometre per million years $\quad \mathrm{km} / \mathrm{Ma}$

$\mathrm{kg} / \mathrm{m}^{3}$

$t / m^{3}$ 
